\title{
ОСОБЛИВОСТІ ФОРМУВАННЯ САМОВИЗНАЧЕННЯ МАЙБУТНІХ СОЦІАЛЬНИХ ПРАЦІВНИКІВ В УМОВАХ УНІВЕРСИТЕТУ
}

\author{
Бодрова I. O. \\ аспірантка кафедри теорії та технології сочіальної роботи \\ Національний педагогічний університет імені М. П. Драгоманова \\ вул. Пирогова, 9, Київ, Украӥна \\ orcid.org/0000-0003-3510-0039 \\ iabodrova@gmail.com
}

\section{Ключові слова:}

самовизначення, професійне самовизначення сочіальних прачівників, прочес становлення сочіального працівника, професійний розвиток, освітнє середовище.
У статті описано особливості формування самовизначення майбутніх соціальних працівників в умовах університету. Репрезентовано вплив університету на професійну діяльність майбутнього соціального працівника - це можливість вибору фахівцем соціальної роботи власного шляху самовизначення, який обирається самостійно, не нав'язується ззовні; використання достовірних інформаційних потоків для отримання професійної освіти через урахування впливу різних громадських організацій, культурно-просвітницької діяльності. Описано етапи професійного самовизначення майбутніх соціальних працівників в умовах університету: професійне самовизначення, професійний розвиток, професійне становлення. Охарактеризовано особливості кожного $з$ етапів професійного самовизначення майбутніх соціальних працівників в умовах університету: усвідомлений вибір професії 3 урахуванням власних можливостей і здібностей, вимог професійної діяльності та соціально-економічних умов, професійна адаптація, підвищення рівня професіоналізму, набуття професійного авторитету, досягнення активності, самостійності, творчого підходу у професійній діяльності. Доведено роль університету у формуванні самовизначення майбутніх соціальних працівників. 3'ясовано, що наслідком такого процесу є підвищення рівня професійного самовизначення майбутніх соціальних працівників за умов повного розкриття фахового потенціалу та використання наявних можливостей особистісного самовизначення. Роль університету у процесі формування самовизначення майбутніх соціальних працівників репрезентовано через освітнє середовище університету. Освітне середовище університету описано як багатокомпонентну систему, де головною $є$ наявність науково-обгрунтованого, професійно спрямованого плану освітнього процесу, який базується на самовизначенні майбутніх соціальних працівників. Зроблено висновок про те, що самовизначення майбутніх соціальних працівників в умовах університету диференціюється насамперед за рівнем освіти, професійної кваліфікації, особистісних якостей та ресурсів. 


\title{
FEATURES OF FORMATION OF FUTURE SOCIAL WORKERS' SELF-DETERMINATION IN THE CONDITIONS OF THE UNIVERSITY
}

\author{
Bodrova I. O. \\ Postgraduate Student at the Department of Theory and Technology of Social Work \\ National Pedagogical Dragomanov University \\ Pirogov str., 9, Kyiv, Ukraine \\ orcid.org/00000003-3510-0039 \\ iabodrova@gmail.com
}

Key words: self-determination, professional self-determination of social workers, the process of becoming a social worker, professional development, educational environment.

\begin{abstract}
The articledescribesthe features of theself-determinationformation offuture social employees in the university. The influence of the university on the professional is represented, the activity of the future social worker is an opportunity to choose a specialist social work of their own way of self-determination, which is chosen independently, no imposed from the outside; use of reliable information flows to obtain vocational education by taking into account the influence of various public organizations, cultural educational activities. The stages of professional self-determination of the future social workers in the university are described: professional self-determination, professional development, and professional development. The peculiarities of each stage self-determination of future social workers in the university are described professional: conscious choice of profession taking into account their own capabilities and abilities, requirements professional activity and socio-economic conditions, professional adaptation, improvement level of professionalism, gaining professional authority, achieving activity, independence, creative approach in professional activity. The role of the university in formation of the future social workers self-determination was brought. It turned out that the consequence of such process is increasing of the level of professional self-determination of future social employees under the conditions of full disclosure of professional potential and use of existing ones opportunities for personal self-determination. The role of the university in the formation process self-determination of future social workers is represented through education university environment. The educational environment of the university is described as multicomponent system, where the main thing is the presence of scientifically sound, professionally oriented plan of the educational process, which, in turn, is based on self-determination of future social workers. It is concluded that self-determination of future social workers in the university differentiated primarily by level of education, professional qualifications, personal qualities and resources.
\end{abstract}

Постановка проблеми. Сучасне реформування соціальної сфери, потреба в розробленні інноваційних моделей надання соціальних послуг різним категоріям населення України, наявність неузгодженості у міжвідомчій взаємодії та можливості державної соціальної політики потребують якісної підготовки конкурентоспроможних фахівців у галузі соціальної роботи.

Соціальні виклики і ризики сьогодення зумовлюють нові вимоги до майбутніх фахівців соціальної сфери ще на етапі навчання в університеті, що актуалізує потребу створення в закладах вищої освіти інноваційного освітнього середовища, де професійне самовизначення майбутнього соціального працівника займає одне із пріоритетних місць.
Професійна діяльність соціального працівника зумовлена особливістю соціальної ситуації у соціумі: низьким рівнем соціальної активності молоді, особливістю характеру взаємин старшого і молодшого поколінь, збільшенням кількості асоціальних груп, зміною цінностей або нехтуванням цінностей попередніх поколінь, низьким рівнем життя, невмінням адаптуватися та знаходити вихід у складних життєвих ситуаціях. Саме це породжує бажання до якісної підготовки фахівця у соціальній сфері, мобільного спеціаліста, що володіє нестандартним типом мислення, орієнтованим на індивідуально-творчий стиль професійної поведінки, потреби самостійно вибирати стратегію і тактику дій у мінливих соціально-педагогічних умовах [6, с. 112]. 
Різні аспекти самовизначення репрезентовані у багатьох дослідженнях: Г. Балла, І. Беха, М. Боришевського, І. Зязюна, Г. Костюка, Н. Ничкало, П. Перепелиці, В. Рибалки, В. Семиченка, О. Скрипченка та інших. Психічний процес професійного самовизначення описували такі вчені, як: Б. Ананьєв, О. Голомшток, Ф. Гоноболін, Є. Клімов, В. Моляко, В. Моргун, О. Мороз, Д. Ніколенко, Н. Побірченко, В. Синявський, В. Сластьонін, М. Смульсон, Б. Федоришин та інші. Знаходженням способу управління процесом професійного самовизначення займалися такі науковці, як: Є. Клімов, Н. Пряжніков, В. Сидоренко, М. Тітма, Л. Божович, О. Леонт'єв, О. Мельник, С. Чістякова та інші.

Досліджувана нами проблема професійного самовизначення майбутніх соціальних працівників в умовах університету недостатньо описана у всіх необхідних аспектах успішної професійної діяльності сучасного фахівця соціальної сфери i не розглядалася самостійно. Варто взяти до уваги, що професійне самовизначення майбутніх соціальних працівників, як правило, порівнювалося з вимогами суспільства до фахівців певної сфери. Саме тому професійне самовизначення майбутніх соціальних працівників в умовах університету є проблемою сьогодення та потребує ефективних шляхів вирішення.

Мета статті - обгрунтування особливостей професійного самовизначення майбутніх соціальних працівників в умовах університету.

Виклад основного матеріалу дослідження. Проведений аналіз наукової літератури дав змогу трактувати поняття «самовизначення» як розуміння і використання особистістю власних особливостей, можливостей, здібностей 3 наявним рефлексивним компонентом.
Самовизначення особистості може розглядатися на кожному етапі її становлення. Вважаємо за доцільне звернути увагу саме на період становлення соціального працівника у закладі вищої освіти, зокрема, період професійного самовизначення. Виокремимо і те, що серед проявів досліджуваного явища $\epsilon$ професійна діяльність, яка розглядається як специфічна форма активності особистості в умовах університету.

Відзначимо, що процес професійного самовизначення $є$ складним процесом розвитку і становлення особистості та потребує різновекторних зусиль. Якщо розглядати професійне самовизначення у системі, то до його компонентів можемо віднести особистісне самовизначення і професійне самовизначення. Зазначенні компоненти перебувають у постійній взаємодії.

В українському педагогічному словнику наведено тлумачення досліджуваної нами дефініції: «професійне самовизначення - це процес прийняття рішення особистістю щодо вибору майбутньої трудової діяльності, який полягає в усвідомленні особистістю себе як суб'єкта конкретної професійної діяльності та передбачає самооцінку людиною індивідуально-психологічних якостей $\mathrm{i}$ зіставлення своїх можливостей із психологічними вимогами професії до спеціаліста» [4, с. 275].

Наголосимо, що професійне самовизначення це соціалізований шлях гармонійного розвитку особистості, поєднаний зі здобуттям професійно-практичного та духовного досвіду в період навчання у вищій школі та вдосконаленням фахового зростання у процесі виконання професійних ролей та обов'язків, що $є$ невіддільним атрибутом розкриття і здійснення особистісного професійного потенціалу [6]. Саме тому варто розглядати

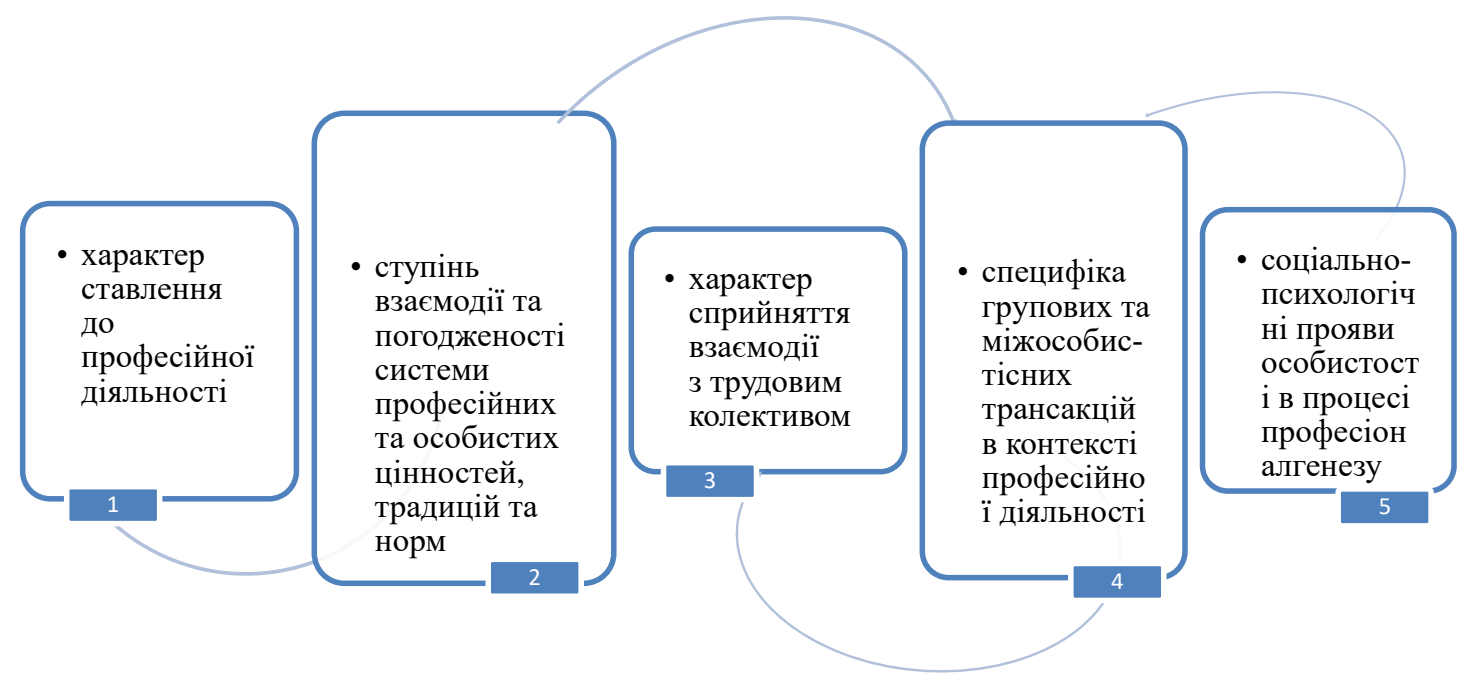

Рис. 1. Основні складові частини професійного самовизначення соціального працівника

Джерело: опрацьовано автором 
професійне самовизначення соціального працівника через призму процесу його соціалізації.

Вважаємо за необхідне виокремити основні складові частини професійного самовизначення соціального працівника (рис. 1) [2].

Відзначимо, що професійне самовизначення майбутнього соціального працівника характеризується взаємним впливом індивідуальних особливостей молодого фахівця і соціального середовища у процесі отримання професійної освіти. Це засвоєння майбутнім соціальним працівником професійних цінностей, набуття ним професійного досвіду, професійних та соціальних зв'язків, реалізація своїх здібностей, інтересів та потреб у процесі здійснення професійної діяльності.

Діяльність соціального працівника передбачає ідентифікацію особистості із професією, злиття 3 діяльністю, за яких професійні риси починають проявлятися в усіх інших сферах життєдіяльності та визначають характер ставлення особистості до навколишнього середовища [6, с. 113].

Науковці визначають поетапну структуру професійного самовизначення (рис. 2).

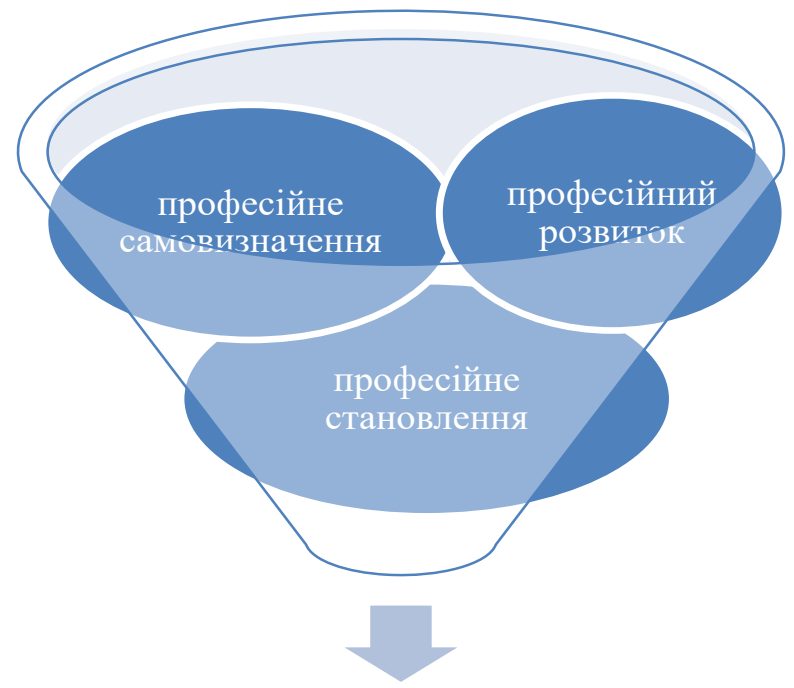

структура професійного самовизначення

Рис. 2. Структура професійного самовизначення

Джерело: опрацььвано автором

До першого етапу відносимо професійне самовизначення майбутнього соціального працівника. Під означеним етапом розуміємо вибір професії 3 урахуванням всіх їі особливостей і уявленням можливих перспектив у професійній діяльності. Відзначимо, що цей етап передбачає реальне оцінювання власних можливостей i здібностей у відповідності вибраному фаху, а також розуміння висунутих вимог до професії майбутнього соціального працівника. Невід'ємним елементом на означеному етапі $\epsilon$ розуміння i врахування соціально-економічних та політичних умов.

Наголосимо на тому, що професійне самовизначення особистості здійснюється протягом усієї професійної діяльності - від закінчення закладу середньої освіти та вступу до закладу вищої освіти, від підвищення кваліфікації до зміни посади тощо. Під час самовизначення майбутній соціальний працівник має бажання змінювати процеси життєдіяльності усього суспільства та відчувати наслідки власних дій у своєму житті.

Наступним етапом професійного самовизначення соціального працівника виокремлено «професійний розвиток». Саме цей етап розпочинається в умовах університету. Наслідком цього етапу $є$ повноцінне формування професійної адаптації майбутнього соціального працівника, його професійного розвитку. Зауважимо, що професійний розвиток майбутнього соціального працівника базується на розвитку особистості взагалі, на засвоєнні отриманого досвіду, знань, умінь; на практичній складовій частині навчання (практичному застосуванні отриманих знань як в особистій, так і у професійній діяльності); наявності бажання до постійного професійного саморозвитку і самовдосконалення. Репрезентований нами етап професійного самовизначення майбутніх соціальних працівників має прямий вплив на перетворення особистістю свого внутрішнього світу і стає одним із головних етапів системного і творчого підходів до професійної діяльності.

Останнім етапом, не менш важливим для професійного самовизначення в умовах університету, є професійне становлення. Етап професійного становлення передбачає підвищення рівня професіоналізму соціального працівника в умовах університету. Наслідком цього етапу стає формування професійного авторитету як серед суб'єктів професійної діяльності соціального працівника, так і серед колег. Відзначимо, що одним із найцінніших результатів етапу професійного самовизначення $\epsilon$ повне визнання соціальним працівником власної професії i iï необхідності для сучасного соціуму і світу. На третьому етапі соціальний працівник досягає активності, самостійності, творчого підходу у власній професійній діяльності [3].

Варто зауважити, що формування самовизначення майбутніх соціальних працівників в умовах університету $\epsilon$ незаперечним, адже сучасні заклади загальної середньої освіти не стають сполучною ланкою між зрілою особистістю та майбутнім вибором іiі професійної діяльності. Саме цей обов'язок, відповідно до запитів суспільства, має взяти на себе заклад вищої освіти. 
Зазначимо, що освітнє середовище університету - це багатокомпонентна система, головним компонентом якої $є$ наявність науково обгрунтованого, професійно спрямованого плану освітнього процесу, який базується на самовизначенні майбутніх соціальних працівників. Наявність такого плану передбачає інтеграцію знань, використання міжпредметних зв'язків, під якими розуміємо певні логічні зв'язки між навчальними дисциплінами, що формують цілісне уявлення про явище суспільства, допомагають інтегрувати отримані знання з різних навчальних предметів у практику [5, c. 79].

Поділяємо думку науковців, які зазначають, що «освітнє середовище закладу вищої освіти - це загальний, сукупний, об'єднаний, інтегральний, цілісний чинник розвитку особистості, що відіграє визначальну роль у модифікації поведінки, яка розгортається внаслідок як запланованих, так і незапланованих чинників середовища, сприяє особистісному і професійному розвитку»; «освітне середовище закладу вищої освіти - це багатосуб'єктне та багатопредметне утворення, що цілеспрямовано і стихійно впливає на професійно-особистісний розвиток майбутнього фахівця, забезпечуючи його готовність до професійної діяльності та продовження навчання, успішного виконання соціальних ролей та самовизначення у процесі життедіяльності» [1].

Зауважимо, що нині переваги успішного самовизначення майбутніх соціальних працівників позитивно впливають на сучасний соціум. Тому сформоване самовизначення майбутніх соціальних працівників в умовах університету стає розширенням їхніх освітніх «горизонтів» і спонукає до процесу формування та розвитку компетентних громадян XXI століття, яких потребує кожна країна і світ загалом. Самовизначення майбутніх соціальних працівників - це внутрішнє самовдосконалення кожного фахівця, яке базується на стабільних цінностях і потребі у постійному саморозвитку.

Висновки. Аналізуючи зазначене вище, можемо узагальнити, що професійне самовизначення майбутнього соціального працівника пов'язане з повним розумінням своєї професійної діяльності. Незаперечним показником у досліджуваному нами процесі $є$ розуміння і втілення професійної перспективи, де простежується прямий зв'язок життєвих і професійних очікувань, ціннісних орієнтацій майбутнього соціального працівника і його життєвого кредо разом із професійними планами.

Самовизначення майбутніх соціальних працівників в умовах університету формується в тому разі, коли студент самостійно знаходить шляхи вирішення конкретних завдань, виявляючи при цьому нестандартне мислення. Це визначення варто розуміти не лише як фахову підготовку до професійної діяльності, а й як його спеціалізацію. Ефективне формування досліджуваної проблеми є можливим лише тоді, коли процес здійснюється в адекватних освітніх формах. Існування таких форм розвиває у майбутніх соціальних працівників уміння діяти ефективно та успішно адаптуватися до професійної діяльності. Наслідком такого процесу стає підвищення рівня професійного самовизначення майбутніх соціальних працівників за умов повного розкриття фахового потенціалу та використання наявних можливостей особистісного самовизначення. Соціальний працівник має бути гуманним, поважати людину, яка потребує допомоги, підтримувати ï професійно і морально, надихати на подолання труднощів, розв'язувати проблеми, вселяти віру у власні сили й можливість повернення до гідного життя.

\section{ЛІТЕРАТУРА}

1. Братко М.В. Освітнє середовище вищого навчального закладу: пошук стратегій управління. Педагогічна освіта: теорія і практика. Психологія. Педагогіка. 2014. № 22. С.15-21.

2. Богатырева О.О. Личностные факторы профессиональной самореализации : дис. ... канд. психол. наук : спец 19.00.01 Общая психология. История психологии. Москва, 2009. 162 с.

3. Гупаловська В.А. Професійна самореалізація як чинник становлення особистості жінки : автореф. дис. ... канд. психол. наук : 19.00.01; Ін-т психології ім. Г. С. Костюка АПН України. Київ, 2005. $25 \mathrm{c}$.

4. Гончаренко С.У. Український педагогічний словник. К. : Либідь, 1997. 376 с.

5. Дячок Н.В. Формування професійної мобільності майбутніх учителів інозених мов в освітньому середовищі університету: дис... канд. пед. наук : 13.00.04 ; Київський університет імені Бориса Грінченка. Київ, 2019, 268 с.

6. Руденко Ю.Ю. Професійна самореалізація майбутніх соціальних працівників. Педагогіка формування творчої особистості у вищій $і$ загальноосвітній школах. 2019 р., № 64, Т. 2. С. 112-117.

7. Соціальна педагогіка : словник-довідник / за заг. ред. Т.Ф. Алєксєєнко. Вінниця : Планер, 2009. $374 \mathrm{c}$. 


\section{REFERENCES}

1. Bratko M.V. (2014) Osvitnie seredovyshche vyshchoho navchalnoho zakladu: poshuk stratehii upravlinnia [Educational environment of higher educational institution: searching for management strategies]. Pedagogical education: theory and practice. Psychology. Pedagogy. Vol. 22. P. 15-21.

2. Bogatyireva O.O. (2009) Lichnostnyie faktoryi professionalnoy samorealizatsii [Personal factors of professional self-realization]: dis. ... kand. psihol. nauk : spets 19.00.01 Psychology. History of psychology. Moscow. $162 \mathrm{p}$.

3. Hupalovska V.A. (2005) Profesiina samorealizatsiia yak chynnyk stanovlennia osobystosti zhinky [Professional self-realization as a factor in the formation of a woman's personality] : avtoref. dys. ... kand. psykhol. nauk: 19.00.01. Institute of Psychology. GS Kostyuk, Academy of Pedagogical Sciences of Ukraine. Kiev. 25 p.

4. Honcharenko S. U. (1997) Ukrainskyi pedahohichnyi slovnyk [Ukrainian pedagogical dictionary]. K. : Lybid. 376 p.

5. Diachok N.V.(2019)Formuvannia profesiinoi mobilnosti maibutnikh uchyteliv inozenykh mov vosvitnomu seredovyshchi universytetu [The professional mobility formation of the future language teachers in the educational environment of the university]: dys. ... kand. ped. nauk : 13.00.04. Borys Hrinchenko Kyiv University. Kiev. 268 p.

6. Rudenko Yu.Yu. (2019) Profesiina samorealizatsiia maibutnikh sotsialnykh pratsivnykiv [Professional self-realization of future social workers]. Pedagogika formuvannya tvorchoyi osoby stosti $u$ vy shhij $i$ zagal noosvitnij shkolax. Vol. 64. P. 112-117.

7. Sotsialna pedahohika: slovnyk-dovidnyk (2009) [Social pedagogy: dictionary-reference book] / za zah. red. T.F. Alieksieienko. Vinnytsia: Planer. 374 p. 